STATE PLANT BOARD

Unlted States Department of Agriculture

Agricultural Research Administration

Bureau of intomolog and Plant Quarantine

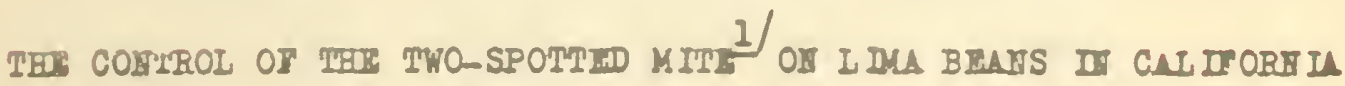

\author{
By John C. Imore, D1v1810n of \\ Track Crop and Garden Insect Invest1gat1ons?
}

The demsere carsed by the tro-spotted mite to 1 ima beans in Orange and Los Angeles Count108, Cal11.. since 1941, bas made control neasures necessary. Salfur bas long been recogelzed as the reand for thls pest on cultivated crops, but 1te application has not al- . way resulted in sat1sfactory control. woerimonts ado during 1943 to doteralice when and how to apply ralfur to 1 ims besss for alte control and to derelop rupplementary mearures of control bave led to the suggestions given in this clrcular. These should ald the bean grower in Callfornia in protecting his beans.

\title{
Whon to Lpply salfur
}

Ina bean in southion Callfornla can be protected from approclable mite injury by one or two eppllcat1ons of "cond1t1oned dustInf sulfur. The perlod in which applications are made, with respect to crop growth and mite infestation, is the important factor. It has been found that, to be most successful, sulfur should bo applled w1thIn a period fron 40 to 60 dars after planting. The mites do not bo cone numeroue enough to damage the crop wat1l more than 40 daje after plant1ng. On tho other hand, application need not bo made later than 60 day after plantlag to protect the plants for the rest of the season. Whe dusting perlod for bean planted Mar 1 vould be from June 10 to 30 and for those planted May 15 it yould bo from June 25 to Jaly 15. Dar Ing these perlod the plant are emell anough to permit dusting equipment to pass through without plant damage and to make control possiblo by use of a soderate anount of sulfar per acre. Experimental plots dusted 30 dare after planting became hearlly lafested before hartesttine. Plot dacted 67 to 77 dass after plenting required a larger amount of sulfur per acre, and the plants vere danaged because they were too large to allov tho dusting equipment to pass through Ireely.

1) The nane "two-spotted $m 1 t^{*}$ is proposed for Tetranzchas b laaculatus Earrej. one of the several specios that bave been konow as conon red eplders, or plder mites.

2) The author wiabes to ackowledge the cooperation and as1. 1ance of the Dopartiment. of Agrloulture of Orange and Los Angeles countien in the 1101 d work done on this problea. 
Dasting shoald be done when there is little or no alr movenent -1ther at aight or during the morning before the wind becomes too strong to permit thorough coverage of the plants.

\section{Jumber and Rate of Applicat1one}

In stuations not previously subject to serlous mite damege, such as locel1t1es where alfalfa is not belng grom, one application of dustIng sulfur at the rate of 30 pounds per acre. 45 to 50 dajo after planting, 18 reconmended. In localities subject to early or heavy mite infestat10ns, or where thore 18 a possibllity of serlous mite danage, two applications of sulfur should be made, at 30 and 50 pounds per acre, respect1vely, the f1rst 40 to 45 days after planting and the second about 2 weeks later. The second application need not cover more than 64 mar ginal fors on each side of the field and a border of the same width across each end.

\section{Dasting Iquipment}

The most eat1sfactory dusting aachines for lima boans are of the row type capable of covering eight row at a time and mounted on, or pullod by, tractore. It is rery isportant to get the dust orenif distributed on the under ides of the leaver. This can bo done by using dusting machines equipped with nozzles to direct the dust to both sides of cach row. If one ontlet per row 10 used, the dust can be directed to the under o1des of the leares with a I nozzlo carried botween the rows. If two outlets per row are used, the nozzles ahould be 80 directed that the dust strikes the plants Irom both sides and Irou bolow. In the case of \&row dustors, larger air rolume and lees frlction w11l bo obtalned with olght 2-inch tubes or outlets then with sixteen lt-inch tubes. Wen nozsles or tubes become clogged with dust materlal, they ray be cleaned by running a anall anount of scouring sand through the machine.

The cost of castom dusting in 1943 ranged from $\$ 2.50$ to $\$ 5.00$ per hour for labor and equipment, plus \$1.00 to $\$ .65$ per acro for oulfur. With 8-row dusters, from 8 to 10 acren wore unally dusted per hour. This dusting remulted in an increased jield ranging fran 400 to 500 pound in some flelds as compared with the jleld from untreated areas within the $1101 \mathrm{ds}$.

\section{Ind1rect Control}

Ans practice that reduces the mamber of mites on other nearby Infested plants early in the season will tend to roduce infestation in the bean flelds'. Thereforo, the treatment of alfalf, roadsides, or other sources of nite Infestation. with sulfur early in the season is of value. Ifkewise, the destruction, along roadsides and ditch banks, of morning-glory plants and other weods that are lnfested with the tro-rpotted 
nite w111 help to control this pest.

Caution: Dast goggles should bo worn when sulfur 18 being handed, ince it is Irritating to the ejes. Wo Irritation 18 mach ore severe during dusting operetions than at threahing time. Onless the amount of salfur used per acre 18 far in excess of the amount recomended, oje irritation at throahing time 18 slight and 18 usuall not not1ceable untll the ejos and face are vashod. Precartion should be taken to prevent the sulfur from lgniting during dusting operat10n. labber-t1red tractors and dustors should bo grounded by a dragging chain. sulfur bould bo kept aray from hot motors and motor exhausts.

Description and Hab1ts

The tro-spotted mite, or common red spider, is a tiny opider11 te ereature not quite large enough to be readily seen with the nated oje. It 18 umally redd1sh, but the color mas range from yellow, orange, or brom, to green, and often, but not always, it bas two minuto dark ppots on tho upper part of the body. Soreral kinds of spider mites will foed on I Ina beans, but during 1943 the two-spotted mite was commonly found on thls crop. W1th the latter the green color mas predominate during midsumer when the plants are green and succulent. Howerer, mans red, yellow, orange, or brom two-epotted mites may always bo found. Ls the season adrances, mot of the mites mar be orange or red.

The adalt females 1 ar 6 or 7 eggs per dey. The joung mites that hatch from these eggs grow rery rapldy and may matare in 10 dars. Onder low temperatures thej do not develop so fast, but under hligh tonperatares mites increase so rapldiy that they seem to appear ouddenly in Ilma bean flelds and maj carse conslderable damage bofore they are noticed.

The tro-spotted mite 18 able to 1170 and develop on a wide varioty of plants. It 18 difflcult to nome a cultivated plant upon whlch it has not been found, and after the beans have been harvested 1t w111 foed on almost an avallable woods. Norning glory 18 a conmon food plant, and alfalfa is the most consplcuous cultivated food plent assoclated with Ilma beans. Whe mites are apparentiy ablo to currive the winter and bulld up in the spring more ruccessfully on alfalfa than on other plents around lima bean flelds. By the time the beans are up, the mites may already bo developing on alfalfa. In man bean flelds, especially in those formerly in alfalfa, the ites are often present and well distributed on the plants by the time the trifollate bean leares appear. The cutting and bauling of grean alfalfa is a well-knom means of scattering the mites. Th1s dimereal 1s especially noticeablo in bean flelds to the leoward of alfalfa flelds and along the roads were stalks of hay are lost from the hay trucks as they pass. Needy ditch banks and roadsides, 2. well as farm gardens and home yaxds, are I1kowlse important

sources from which mites spread to nearby bean flelds. 


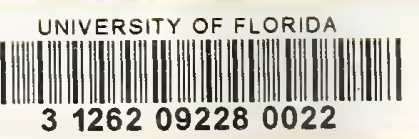

